\title{
Case Study: Helping Corporate Board Members Stay Diligent
}

\section{(Post-Enron)}

\author{
Renee A. Pistone \\ Insurance \& Corporate Defense Litigation, Specialty: Alternative Dispute \\ Resolution (ADR), B\&R Associates, Inc. \\ Faculty, Rutgers University Writing Program \\ Business \& Professional Writing, New Brunswick, NJ, USA \\ E-mail: rpistone@fas.harvard.edu
}

\begin{abstract}
The Enron financial scandal impacted Wall Street and Board rooms within multinational corporations. Board Members need guidance in order to prevent fraud and abuse. The attorney featured in the following hypothetical faces serious ethical dilemmas. This hypothetical is unique because it involves an attorney Board Member facing ethical problems within a large business organization, as opposed to a one-on-one attorney-client situation. Here, the attorney Board Member, has a significant financial stake in the outcome. Certain issues will be delved into and analyzed according to customarily accepted Ethical standards for Board Members. Later on, this article is supplemented by federal and state case law. Supplemental cases were specifically chosen to emphasize and relay certain key principles of black letter law. Also, this article offers Board Members some reasonable alternatives to follow in order to follow due diligence.
\end{abstract}

Keywords: Due diligence, Reasonably necessary, Disaffirm, Criminal recklessness

\section{Introduction}

Every corporation's purpose and mission is to generate wealth for its shareholders. The Enron scandal left creditors struggling to recoup their money as they were victims of unprecedented corporate greed (Malito \& Wiener, 2009). Eight former Enron executives received plea agreements that featured jail terms up to twenty-four years (Hays, 2007). Also, the past years featured rampant corporate bankruptcy that continues to plague worldwide financial markets hampering economic recovery efforts (Cowen, 2009). Truly, the seriousness of these problems cannot be underscored enough.

\subsection{Case Study Hypothetical}

I missed the past five Board meetings of my company. Our Board Chairman sent me on a two month ski vacation to Aspen. He said that I needed to rest. The sixth Board meeting just began and I walk in late. The Board is discussing a proposal from the Chairman. My company is BMS and it is a multi-billion dollar American pharmaceutical corporation headquartered in Delaware. BMS is experiencing significant cash flow problems and increasing operations costs. Currently, Wall Street analysts have downgraded our stock from "buy" to "hold." The proposal to be voted on is about a plan to sell an abortion drug called ZT444 to women in certain developing Arab nations in the Middle East. This plan has been expanded to include Israel. BMS plans to sell ZT444 in these nations without any warning labels (and without a Doctor's prescription) "over-the-counter." The missing warning labels include that the drug may cause permanent infertility in five out of five thousand women. Also, ZT444 may cause death in one out of five thousand women. Finally, it must never be mixed with alcoholic beverages or temporary blindness may result. BMS also plans to sell and market ZT444 in the United States as BMS just gained Federal Drug Administration (FDA) approval. In the United States, however, ZT 444 will be made available by prescription only and ZT444 must contain the warning labels in conformance with guidelines. During the drug testing trials (to gain FDA approval) BMS conducted substantial scientific research. In fact, BMS tested ZT444 on adult female volunteers. These female volunteers remain anonymous known only to the Board's Chairman Asa Buchanan. Although no volunteer died during the trials, a young woman died mysteriously shortly after the testing ended. The woman's family and the county coroner were unaware she was involved in the drug testing trials. She was sixteen years old and had lied to BMS about her age. The county coroner will not be able to make the causal connection necessary to permit the young woman's estate to sue BMS. At this point, I gesture to speak and the Chairman ignores me. He shrugged and barked that it's a 
coincidence. Then the Chairman said, "Everyone here can appreciate how hard it is to prove any wrongdoing. In this tight market, BMS simply cannot afford bad publicity." Further lamenting, the Chairman decries, "and of course, BMS can always settle for a low ball figure if anyone sues." I am silent and a little shocked. I am an attorney of Jewish descent (with strong ethical values-as my father is a Rabbi). I lived in Israel for ten years and have many family and friends there. I am also the Chief Executive Officer, and a Board member with a $65 \%$ share of company stock. The Chairman of the Board has now asked me to present my opinion and recommendations on how to proceed. Our next meeting will be in two weeks. I am the only lawyer in the room. A preliminary vote is taken and it's clear that I am the only one in an ethical quandary. The Board members are fearful that the corporation may become insolvent. I feel a strong sense of conflict about selling ZT444 without warning labels in Israel, a place dear to me. I also think that there may be a causal nexus between the woman's death and ZT444. I have a fiduciary duty to the Board that I must consider before I act. The meeting is getting ready to adjourn and the Chairman said that he anticipates litigation from advocacy groups. Also, there may be problems from the federal government if it should stop BMS from exporting ZT444 without warning labels. The Chairman asks me to personally see to it that any challenges by the federal government in the form of injunctions are lifted. The Chairman further beckons me to contact David Lieberman, a former business associate who is a high ranking foreign official in Israel. BMW needs his help to expedite and ease the marketing and sale of ZT444 there. The Chairman tells me to inform David that ZT444 is "totally safe." Then, the Chairman asks another Board member, in my presence, to use his "influence" with Rashid Amad, a well respected businessman known in powerful sects within Middle Eastern countries. The Chairman adds, “when I say 'influence,' I mean, do whatever is necessary." The Chairman then concludes by saying that, if the sales of ZT444, especially outside the United States, are not as expected and corporate earnings drop in the next quarter; then, BMS must lay off half of our workforce. Additionally, BMS will be forced to end its humanitarian "grants program" money that is used by private organizations to end hunger and to fight the spread of infectious diseases worldwide. Ultimately, BMS will end up insolvent, the Chairman adds.

\section{Due Diligence and Compliance}

The problem is that there are numerous consequences that board members face stemming from unprofessional conduct. Certainly, these consequences include public disfavor and possible fine and imprisonment (Levin, 2009).

\section{Example: 1. Compliant Board Members}

The example below illustrates the tensions that real world board members experience: As the meeting concludes, the Chairman walks me out. I explain to him that we need to talk in private. Asa invites me to his home for cocktails. There, we discuss the plan while playing billiards and drinking brandy. We are both relaxed. He offers me a cigar and I decline. Asa said that he needed my support and he needed me as CEO to carry out the plan. I explain that the plan will not work. Asa barks, "I want documentation and details about why the heck not." I said, "Asa you and I go back many years and we served two terms in Congress together." I said that, you always helped me secure the votes I needed to help give foreign aid to Israel to please my constituents. But I always helped you get the votes that you needed to help you with your constituents.

I said, lets put our ego's aside for a minute. When I nominated you to be Chairman ten years ago, I knew then, what I still feel is true today, that there is no person better qualified. I know that deep down inside that you do not want to sell a drug without any warning labels. That is something that BMS has never done and we have been in business-some fifty years now. As an attorney, I am going to first advise you, as Chairman, and my old friend, in compliance with international rules for doing business, "a lawyer employed or retained by an organization represents the organization acting through its duly authorized constituents." You are an appropriate official representative of our organization. But I shall advise the Board collectively, at the next meeting, in conformance with the due diligence principles, "a lawyer shall explain a matter to the extent reasonably necessary to permit the client to make informed decisions regarding the representation." You know that I am required to give you my honest opinion about the actual consequences that appear likely to result from your conduct. Asa, I want you to know that "if a lawyer for an organization knows that an officer, employee or other person associated with the organization is engaged in action, intends to act or refuses to act in a matter related to the representation that is a violation of law that reasonably might be imputed to the organization, and that is likely to result in substantial injury to the organization, then the lawyer shall proceed as is reasonably necessary in the best interest of the organization. Unless the lawyer reasonably believes that it is not necessary in the best interest of the organization to do so, the lawyer shall refer the matter to higher authority in the organization, including, if warranted by the circumstances to the highest authority that can act on behalf of the organization as determined by applicable law." 


\subsection{Disaffirm fraudulent activities}

Corporate officers provide plans and strategies for the on-going management of the business. The difference is that corporate directors are charged with providing leadership decisions for management. It certainly involves more responsibility as corporate directors must carefully recommend policies that are financial sound. Also, they are responsible for evaluating investments that the corporation undertakes.

\section{Example: 2. Actions to Consider}

Asa must understand that if he refuses to take my advice, then I must go on record in the minutes at the next Board meeting to disaffirm all plans for ZT444. I shall also resign from BMS. Therefore, Asa, this rule prohibits a lawyer from assisting a client in conduct that the lawyer knows is criminal or fraudulent. I further explain how damaging it would be if a derivative suit were ever filed by the shareholders and the minutes were read indicating that the only lawyer in the room disavowed and later resigned in conformance with ethical rules for Board Members prevents me from giving notice of the fact of withdrawal. I may also withdraw or disaffirm any opinion or affirmation.

I said, honestly Asa, I cannot allow you and the Board to commit fraud. I shall read the applicable rule. "a lawyer may reveal information relating to the representation of a client to the extent the lawyer reasonably believes necessary: (1) to prevent reasonably certain death or substantial bodily harm; (2) to prevent the client from committing a crime or fraud that is reasonably certain to result in substantial injury to the financial interests or property of another and in furtherance of which the client has used or is using the lawyer's services;" I think that distributing ZT444 without warning labels in Arab nations and in Israel may be criminal. BMS has a duty to warn those consumers. Asa, yells back that if we include the warning labels sales will slump and we will not make enough money to save the company. I said that is simply untrue. Asa, when you asked me to contact my business associate David, the high-ranking foreign official in Israel; you asked me to tell him ZT444 was "totally safe." I did not tell him that but I did furnish him with a report from our scientific research department that indicated the statistics about death and infertility. I may not commit fraud. As the CEO of BMS, I felt that it was prudent and within my authority to send the scientific report to David for him to draw his own conclusion. David then compared it with official Israeli government statistics regarding clinical abortions performed by a Doctor in Israeli. David advised me that having an abortion surgically rather than medically (using ZT444) was actually significantly more dangerous.

\subsection{Board Member Liability for Harm}

The relevant facts of the case are as follows. There was an explosion at one of Warner's chewing-gum plants and several of the employees were killed with many more injured People v. Warner Lambert Corp., (1980). The grand jury reviewed evidence that showed the corporation used two potentially explosive substances in its manufacturing process, magnesium stearate (MS) and liquid nitrogen. Further, the evidence showed that the officers and certain employees were warned by an insurance carrier that the high concentrations of the MS dust, combined with other conditions, created an explosion hazard. These hazards were not eliminated by the time of the accident. The company was sued and several other officers and employees were indicted for second-degree manslaughter under New York Penal Code Annotated sec. 125.10 (West 2000) and criminally negligent homicide. The indictments were thrown out and the court did not find the defendants criminally liable for the employees deaths on the theory of reckless or negligent conduct.

\section{Example: 3. It Could Happen to You}

Asa still needs to be convinced. I said, "my research indicates that you may be criminally liable if you sell ZT444 without the warning labels." I said, "do you understand me?" "I raise my voice, forget about our trip to play golf with Tiger Woods, in Palm Springs next summer, you and the other Board members could go to jail." "I said, Asa I never really told you what happened to those Warner executives that we used to go ballroom dancing with." I said "well, their careers took a dip after being indicted for the deaths of their employees." "But, Asa that was a close call for those executives and some people may think that the case was unfair." Clearly, the case was properly decided based on the applicable criminal law statutes; but, it was not ethical what the Warner officers did and they got away with it. The court found that the "triggering cause of the explosion was neither foreseen nor foreseeable." "Look, Asa, the facts of that case are different from ours." But there are some relevant points of law that come out of the case, for example, in Warner, the defendants were not held liable because their conduct was not "sufficiently direct" causing the deaths under criminal law. "At common law and under the Model Penal Code, if the result that comprises the criminal offense would not have occurred but for the defendant's voluntary act or omission, then "actual cause exists." I said, "but, what would happen if deaths result 
from people taking ZT444 and BMS and our officers are indicted for criminal conduct." I would be negligent in my fiduciary duty if I did not advise you that this could happen. Asa, do not forget about the Pinto case.

\subsection{State v. Ford Motor Corp. (1979)}

The relevant facts of the case are as follows. Three girls were killed when their 1973 Ford Pinto was rear ended and caught fire, State v. Ford Motor Corp., Ind. Code Ann sec.35-41-1-2 (Burns 1979). The jury handed down an indictment charging Ford with three counts of reckless homicide and one count of criminal recklessness. Ford defectively designed the 1973 Pinto so that in a rear impact collision the car would burn up. Ford was found to have recklessly failed to modify the car or warn the public. The indictment stipulated that Ford was responsible for a proximate contributing cause of the deaths of the girls. Likewise, it is not impossible for BMS to be indicted for failing to warn about ZT444 similar to the Warner Lambert and Ford Motor cases. However, based on our facts, the court may rule against us finding that it was foreseen or foreseeable that (an act or omission would result) as in our case deaths from taking ZT444. I said, "BMS' executives, unlike the executives in Warner Lambert and Ford Motor, may suffer more than indictments as they may actually be convicted."

\subsection{Reasonable Reliance}

Fraud is defined in Black's Law dictionary as elements of false representation, intent to deceive, reasonable reliance, and damages. In a case called, Nelson v. United States (1955) the plaintiff appealed a conviction for obtaining goods by false pretenses. It is ironic that the plaintiff was convicted of false pretenses despite no direct evidence of any intent to defraud at the time of property passed. The court found that the intent to injure or defraud in false pretenses is presumed when the unlawful act results in loss and injury.

\section{Example: 4. The Requisite Scienter Requirement}

The problem here is that generally speaking, one knows something is false if she has personal knowledge of its falsity. Clearly, for BMS to claim that ZT444 is absolutely safe, then it is making a statement under false pretenses and that may be a form of actionable fraud. It is certainly questionable enough that, as an attorney, I cannot in good faith recommend that course of action to you and to the Board. "Asa, don't look at me like that-as if I am not getting through to you- I shall be forced to resign from BMS." You do understand the tenuous position I'm in. Asa said, "I can see your point and it now seems absurd for me to insist that the Board approve the plan." I'm going to call a meeting in the morning. So, I guess there is no need for anyone to be bribed. I said, "if I may speak freely, that was a very bad idea and the reason why someone said, 'absolute power corrupts absolutely." Don't start getting philosophical. Asa lamented, "I did not get my MBA from Wharton to go around hurting people." Asa was staring out into his backyard that had black stallions grazing in it. Asa said, "we built this company up from nothing. I still remember the day we took her public. I spilled pink champagne all over the initial public offering." I said, "Oh yes, I spent weeks preparing the I.P.O. and I remember wanting to hit you over the head with the champagne bottle." Asa said, flaunting his ego that is deservedly large, given all he has accomplished at the age of 52, "I vividly recall when we had 100 employees and now we have 100 thousand worldwide." "So, of course, I feel obligated to warn the consumers."

Asa retorted, "I know that I don't have the morals and foresight of a Supreme Court Justice, but I now realize that every woman should know the risks of taking ZT444." He said, "Technically, BMS is safer than surgical abortions and it has a lower death rate than actually giving birth in some of the Arab nations." He smiles and shakes my hand. "We have come a long way." A little stunned I said, "I agree, that is true based on all of our research." "I said it would be appropriate for BMS to market ZT444 and say those things." BMS will include all of the warning labels on ZT444 everywhere it is sold. Asa said, "You are right it's a little cheaper to manufacture in a uniform way, this way, the packers do not have to pack one set of medication with and one set without the warning label information." He said, "Now what about that young girl that died?"

Well, Asa, my buddy, using my clout as CEO, whether real or imagined clout, I should say, I obtained the girl's file from the executive secretary Linda Smith. Asa said, "you always had a way with her." "Sure, I got her a turkey on honey wheat- the usual bribe." He just laughed and said, "Give me a break-you mean you did not have to give her four tickets to the symphony." I said, "Asa you have been getting duped by her all these years." Anyway, I figured out who the girl was after I scanned the list of names in the file. I found her because she was the only volunteer from out of state. I immediately met with the county coroner, who incidentally was on the same crew team with me, when we were in college. Don't worry, I did not tell the coroner exactly why I was there but she figured it out. It would be a breach of my fiduciary duty for me to divulge that information. I was careful not to say anything that might implicate BMS or admit any wrongdoing. The coroner whose name is Judy Bones really opened up to me. Dr. Bones said, "off the record, I'm going to tell you that the girl died from a bad batch of heroine...I want you to be able to sleep at night." Judy told me that she was puzzled at first because the 
girl injected the heroine in between her toes. Judy did not find the needle marks during her first examination of the body. Judy was reading from a copy of her written medical examiner's report.

\section{Handling Sensitive Information Ethically}

It is increasingly common for board members to handle sensitive information. Therefore, it is necessary for members to always to be diligent with that information. Secrecy is often necessary in order to prevent corporate espionage to allow for new products to be unveiled when the corporation designates. Rumor and innuendo have no logical place in the boardroom. Of course, the notion of winning at all costs can and often does spark ethical controversy. Consequently, all conflicts of interest must be fully disclosed as soon as they are realized (Hierschbiel, 2008).

\section{Example: 5. True confessions}

Now, I know that this information severely weakened any lawsuit brought by the girl's estate against BMS. I am confident that BMS would win if the family brought a lawsuit alleging negligence. It has been over a year since the girl's death and since she was in our drug testing trials, it seemed socially acceptable for me to meet with the girl's family. I phoned them and asked her family to meet with me in their home. I wanted to tell them in person the circumstances about how their daughter came to be involved in our drug testing trials. They acted surprised and upset. They confessed to me that they knew that she was pregnant. They told me that they would have wanted her to use ZT444 because of her tender age, they said. But as I was leaving the house, the girl's mother ran out and told me not to feel bad because her daughter used illicit drugs fairly regularly. She had lived a life of "pure hell" as a runaway who turned prostitute. The mother said that her daughter is at peace now, away from that pimp. Now, it all made sense to me. I was wondering how the girl could afford the fake birth certificate and fake identification card that she used to get into the drug testing trials. The pimp must have gotten them for her. I explained to the girl's mother that BMS made it mandatory that BMS agents photocopy the picture identification card and birth certificate that each volunteer brought with them. We carry out this procedure for all drug testing volunteers so ZT444 is no different. BMS took great pains in its screening process to prevent something like this (an underage girl entering into the drug trials program) without at least her parents' knowledge. Parental consent was never an issue because we were supposed to be dealing with women eighteen and over. "I gave my condolences to the family." I offered them nothing monetarily and they asked for nothing. The mother told me that she had no interest in suing BMS. I told her that was not the reason for my visit. I told her that I came there to give my condolences and to explain how BMS has safeguards in place to prevent a young girl under 18 from getting into the drug testing trials. I did not want her to think that we were wanton and careless. I knew that they could not really sue BMS because I spoke to the coroner and already knew the cause of death. The girl's mother also informed me that she has benefited because of our charitable work. She informed me that their son is on full scholarship at Harvard thanks to a grant from our foundation. She then said that everything changed once her husband lost his job and starting drinking. Her daughter ran away because he was abusive to her.

\section{Conclusion}

We know that corporate governance ensures that corporate managers are accountable to shareholders. We live in the post-Enron era that has limited managers' discretion to take risks, and in some cases, to innovate. Largely, in part because of Enron we see that managers' abilities to respond to changing economic times have been hampered. Perhaps, these moves towards even greater accountability (post-Enron) will ensure a renewed strength in capital markets. There may be some additional hidden benefits to tying power to the concept of legitimacy. Corporate power and governance were things that we took for granted. The corporate world seems to be shifting in favor of a paradigm for corporate governance that features more accountability for business decisions. Business decisions impact investors, employees, and the world at large. Legitimate power within the corporate world is yielded ethically. It does not exploit workers, natural resources, or place innocent people in danger of losing their lives. The cases and the examples showed us the devastating implications.

\section{References}

Cowen, T. (2009). Burning Down the House. The Economist, 52 (2), 5-6.

Hays, K. (2007). A Sordid Chapter on Enron Ending: Kenneth Rice Is the Final Figure To Be Punished After Pleading Guilty in the Scandal. The Houston Chronicle, A1.

Hierschbiel, H. (2008). Managing the Dual Roles. Oregon State Bar Bulletin, 68, 9-10.

Laufer, W. (2006). Illusions of Compliance and Governance. Corporate Governance, 6, 239-241. 
Levin, J. (2009). Legal Ethics Liability for Aiding and Abetting: Concern for Lawyers. Chicago Bar Association Record, 23, 53-54.

Malito, N., \& Wiener, T., (2009). On the Nature of the Transferred Bankruptcy Claim. University of Pennsylvania Journal of Business Law, 12, 35-38.

Nelson v. United States. 227 F.2d, 21, (1955).

New York Penal Code Annotated sec. 125.10 (West 2000).

People v. Warner Lambert Corp., 51 N.Y.2d 295(1980).

State v. Ford Motor Corp., 925 Ind. F.Supp. 487 (1979).

United States v. Park, 421 U.S. 658 (1975). 